\title{
Kalapuolisäilykkeiden säilyvyys
}

\author{
MartTi KiesvaARa \\ Valtion teknillinen tutkimuskeskus, elintarvikelaboratorio, 02150 Espoo 15
}

\section{The shelf life of fish semi-preserves}

\author{
MartTi KiesvaAra \\ Technical Research Centre of Finland, Food Research Laboratory 02150 Espoo 15
}

\begin{abstract}
A literature review is presented over the factors that limit the quality of fish semi-preserves. The most important are the changes in fat, microbiological spoilage, and excessive proteolysis.

It is possible to reduce the oxidative changes in fats by anti-oxidants and exclusion of oxygen from barrels and retail packs. The carbonyl compounds are mainly formed after the packs are opened.

The high salt content and the anaerobic conditions in barrel-salted fish inhibit the growth of most microbes. After processing the $\mathrm{pH}$ of semi-preserves decreases and the microbial flora consists mainly of representatives of the family Lactobacillaceae. The shelf life of the products is prolonged by preservatives. The amino acids and soluble peptides which are liberated by enzymatically catalyzed proteolysis diminish the effect of preservatives, possibly by a reaction of the amino groups. A promising preservative is tylosin lactate which has been found very suitable for fish semi-preserves.

Excessive proteolysis which softens the muscle tissue too much may prove to be the most harmful effect. From the quality point of view the muscle tissue has to contain an adequate amount of free amino acids. However, the amino acids may accelerate the enzymatic proteolysis by raising the $\mathrm{pH}$. A high content of salt and acid retards the proteolysis but also weakens the quality. To prolong the shelf life of fish semi-preserves new methods will have to be developed.
\end{abstract}

Vuosittain kulutetuista kalavalmisteista muodostavat kalapuolisäilykkeet suurimman ryhmän. Suosituimpia ovat sillistä valmistetut, kuluttajapakkauksissa myytävät haarukkapalat ja fileet, sekä kilohailista valmistettu maustekala "anjovis». Suolakalana käytetyn silakan osuus on vähentynyt. Suhteellisen vähäiseksi on Suomessa jäänyt myös kylmämarinoitujen valmisteiden saavuttama suosio. Haarukkapalojen, fileiden ja maustekalan menekki perustuu epäilemättä niiden vivahderikkaaseen, kalasta peräisin olevaan makuun.

Kalapuolisäilykkeiden maku muodostuu niiden raaka-aineena käytetyn tynnyrikalan kypsyessä. Kypsymisen aikana kalan proteiineissa tapahtuu 
entsymaattista hajoamista. Lihaskudoksen konsistenssi pehmenee ja hajoamistulokset kuten nukleotidit, aminohapot ja peptidit antavat kalalle kypsän tynnyrikalan maun. Suolatussa silakassa ja marinoiduissa valmisteissa jää proteolyysin osuus varsin vähäiseksi, edellisessä korkean suolapitoisuuden ja jälkimmäisissä happolisäyksen vuoksi. Nämä valmisteet ovatkin huomattavasti mauttomampia kuin muut kalapuolisäilykkeet.

Tutkimuksissa on todettu, että proteiinien hajoamista kypsymisen aikana katalysoivat pääasiassa kalan ruoansulatuselinten umpilisäkkeiden, ohutsuolen ja haiman erittämät entsyymit. Mikrobeilla katsotaan olevan merkitystä lähinnä aromin muodostajina lisätystä sokerista ja vapautuneista aminohapoista. Kalan sisältämällä rasvalla on huomattava vaikutus makuominaisuuksiin. Kuitenkin rasvafraktion muutokset ovat, päinvastoin kuin proteiinien, laadun kannalta haitallisia.

Koska kalapuolisäilykkeet sisältävät aktiivisia entsyymejä ja lisääntymiskykyisiä mikrobeja, rajoittuu niiden säilyvyysaika tavanomaisesti muutamaksi kuukaudeksi. Lyhyt hyllyikä aiheuttaa vaikeasti tasaisena pidettävän laadun ohella huomattavia vaikeuksia kalapuolisäilykkeitä valmistavalle teollisuudelle. Asianmukaisella käsitteyllä voidaan säilyvyyttä kuitenkin huomattavasti parantaa. Säilyvyyttä rajoittavat lähinnä rasvojen muutokset, mikrobiologinen pilaantuminen sekä liiallinen proteolyysi.

\section{Rasvojen muutokset}

Puolisäilykkeiksi valmistettava kala sisältää varsin runsaasti rasvaa. Sillin ja kilohailin rasvapitoisuus on $15-20 \%$, usein enemmänkin. Syksyllä kalastetussa silakassa on rasvaa $6-8 \%$. Kalan rasvan rasvahapoista on jopa $80 \%$ tyydyttymättömiä (LıNko 1967). Kun kudoksessa vielä on aktiivisia lipoksidaaseja, hapettuu rasva helposti. Tällöin syntyvät karbonyyliyhdisteet antavat ja pieninä pitoisuuksina valmisteelle vastenmielisen hajun ja maun. Oksidatiivisten muutosten lisäksi tapahtuu rasvoissa lipaasien katalysoimaa hydrolyysiä.

\section{1 Hydrolyysi}

Rasvojen hydrolyysin saavat aikaan lähinnä kalan kudosten omat lipaasit (Olley ja Lovern 1960). Mikrobiologisella ja ei-entsymaattisella hydrolyysillä on vain vähäistä merkitystä. On mahdollista, että vapautuvat rasvahapot tai niiden reaktiotuotteet inaktivoivat muutoksia katalysoivia entsyymejä. OLLEY ja LOWERN (1960) viittaavat mahdolliseen syy-yhteyteen lipidien hydrolyyttisten muutosten ja proteiinien denaturoimisen välillä. He korostavat kuitenkin, etteivät samanlaiset reaktionopeudet eri lämpötiloissa ole riittävä todiste näiden reaktioiden välittömistä liittymäkohdista toisiinsa. Joka tapauksessa rasvojen hydrolysoituminen alkaa kalojen jäähdyttämisen ja kylmävarastoinnin aikana. Samanaikaisesti proteiinien vedensitomiskyky heikkenee. Nyttemmin on kiinnitetty huomiota formaldehydin osuuteen proteiinien denaturoitumisessa (Castell ym. 1973 b). Kalan proteiinien liukoisuutta pienentää jo 10-200 ppm formaliinia. Tällaisia pitoisuuksia esiintyy ainakin turskan kudoksissa, kun niitä on säilytetty muutamia tunteja $-5^{\circ} \mathrm{C}$ :ssa. Jäätyneiden 
turskan fileiden denaturoitumista näyttää kiihdyttävän entsyymisysteemi, joka muodostaa formaliinia trimetylaminoksidista. Myös dimetylaminilla näyttää välillisesti olevan vaikutusta proteiinien liukoisuuden alenemiseen sekä pakastetuissa että jäitetyissä fileissä (CASTELL ym. 1973 a).

On kuitenkin ilmeistä, että sillissä ja silakassa mahdollisesti muodostuva formaliinimäärät ovat liian vähäiset, jotta niillä olisi merkitystä proteiinien liukoisuuden vähentäjinä. Sen sijaan on saatu viitteitä siitä, että rasvojen hapettuessa muodostuvat karbonyyliyhdisteet reagoivat lysiinin $\varepsilon$-aminoryhmien kanssa ja vähentävät käyttökelpoisen lysiinin määrää (RosENBERG 1974) ja myös proteiinien liukoisuutta. Lipaasien optimaalinen $\mathrm{pH}$-alue on 7-9. Happamuus estää näin ollen jossakin määrin rasvojen hydrolyysiä sekä tynnyrikalassa ( $\mathrm{pH}$ 5.7-5.9) että varsinkin haarukkapaloissa ( $\mathrm{pH}$ 5.0-5.4). Koska hydrolyysin aiheuttamat laatumuutokset ovat suhteellisen vähäisiä, ei sillä juuri ole merkitystä kalapuolisäilykkeiden säilyvyyttä rajoittavana tekijänä.

\section{2 Hapettuminen}

Rasvojen hapettuminen on ketjureaktio, jossa välivaiheena syntyy vapaita radikaaleja (FARmer ja Sutton 1943, FArmer ym. 1943). Reaktiossa happi yhtyy kaksoissidokseen nähden $a$-asemassa olevaan hiileen, jolloin muodostuu hydroperoksideja. Tätä energiaa vaativaa reaktiota kiihdyttävät valo ja lämpö huomattavasti. Reaktio

$$
\begin{gathered}
\mathrm{R}^{*}+\mathrm{O}_{2} \rightarrow \mathrm{RO}^{\circ} \mathrm{O}^{\circ} \\
\mathrm{RO}^{\circ} \cdot \mathrm{O}^{\cdot}+\mathrm{RH} \rightarrow \mathrm{RO} \cdot \mathrm{OH}+\mathrm{R}^{\circ}
\end{gathered}
$$

katkeaa, jos vapaat radikaalit ( $\mathrm{R}^{\cdot}$ ja $\left.\mathrm{RO}^{\cdot} \mathrm{O}^{\cdot}\right)$ poistuvat reaktiosta esim. reagoimalla inhibiittorien, antioksidanttien kanssa. Inhibiittoreina käytetään yhdisteitä, jotka luovuttamalla vetyä herkemmin kuin rasvahappo RH estävät radikaalin $R \cdot$ muodostumisen. Inhibiittorien vaikutusta tehostetaan sulkemalla happi mahdollisimman tarkoin pois kalapuolisäilykkeiden pakkauksista.

\section{21 Antioksidantit}

Kalaöljyissä esiintyvistä luonnollisista antioksidanteista ovat tokoferolit merkittävimmät. LEA ja WARD (1959) tutkivat eri tokoferolien antioksidatiivista tehoa. Tehokkaimmiksi osoittautuivat $\delta, \gamma$ ja $\eta$-muodot, kun taas $\varepsilon$, $\vartheta$ ja $a$-muodoilla oli heikoin antioksidatiivinen vaikutus. Tokoferolien rinnalla vapaat aminohapot toimivat synergistisinä antioksidantteina kalavalmisteissa (Jannesson ja Marcuse 1956). Aminohappojen vaikutus voi perustua niiden kykyyn sitoa pro-oksidatiivisia metalli-ioneja tai regeneroida hapettuneita primäärisiä antioksidantteja. Marcuse määritti eräiden aminohappojen silliöljyn hapettumista hidastavan vaikutuksen (1960). Seuraavasta taulukosta käyvät ilmi eräiden aminohappojen silliöljyn hapettumista hidastavat vaikutukset, kun happojen pitoisuudet ovat 0.001 ja $0.01 \mathrm{M} / \mathrm{l}$.

MARCUSEN mukaan voi aminohapoilla olla myös primääristä antioksidatiivista vaikutusta silloin, kun muita primäärisiä antioksidantteja ei ole läsnä Teho vaihtelee happamuuden ja konsentraation mukaan. Niinpä alaniinin ja histidiinin vaikutukset olivat vähäiset $\mathrm{pH}$ 7.5:ssä, mutta $\mathrm{pH}$ 9.5:ssä jo varsin 
Taulukko 1. Aminohappojen silliöljyn hapettumista hidastava vaikutus (MARCUSE 1960). Vaikutus ilmoitettu reaktionopeuksien suhteena kun aminohappoja lisätty/ilman aminohappolisäystä. Aminohappojen pitoisuudet $0.001 \mathrm{M} / 1$ ja $0.01 \mathrm{M} / 1$.

Table 1. The antioxidative effect of amino acids in herring oil. The effect is indicated as the ratio between the reaction rates in solutions with and without amino acids. The amino acid content is $0.001 \mathrm{M} / \mathrm{l}$ ànd $0.01 \mathrm{M} / \mathrm{l}$.

\begin{tabular}{|c|c|c|}
\hline & $0.001 \mathrm{M} / 1$ & $0.01 \mathrm{M} / 1$ \\
\hline Glutaminihappo - Glutamic acid ................ & 0.92 & 0.74 \\
\hline Metioniini - Methionine …......................... & 0.88 & 0.72 \\
\hline 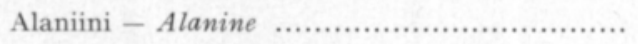 & 0,93 & 0,68 \\
\hline Asparagiini - Asparagine ............................ & 0.88 & 0.66 \\
\hline Valiini - Valine & 0,87 & 0,57 \\
\hline Asparagiinihappo - Aspartic acid ................ & 0.86 & 0.56 \\
\hline 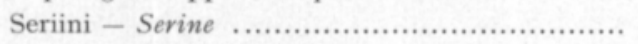 & 0.81 & 0.47 \\
\hline 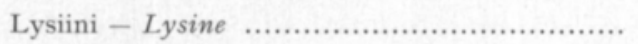 & 0.69 & 0.37 \\
\hline Tryptofaani - Tryptophan & 0.45 & 0.31 \\
\hline Histidiini - Histidine & 0.41 & 0.17 \\
\hline
\end{tabular}

huomattavat. Aminohapon pitoisuuden kasvaessa antioksidatiivinen teho aluksi lisääntyi, mutta väheni sivuutettuaan maksimimikohdan, joka eri aminohapoilla oli hiukan erilainen. Histidiinin ja alaniinin vaikutukset jopa muuttuivat antioksidatiivisista pro-oksidatiivisiksi (MARCUSE 1962). Vastaava muutos tapahtuu myös useilla varsinaisilla primäärisillä antioksidanteilla, esimerkiksi tokoferoleilla.

Yhdessä tokoferolien kanssa aminohappojen suhteellinen vaikutus oli huomattavasti suurempi kuin ilman tokoferoleja. Varsinkin $\mathrm{pH}$ 7.5:ssä oli ero huomattava. Sen sijaan $\mathrm{pH}$ 9.5:ssä tokoferolilisäys vain hiukan tehosti aminohappojen voimakasta vaikutusta (MARCusE 1960).

Varsin mielenkiintoinen on trioktylamiinin antioksidatiivinen vaikutus. Se estää rasvojen hapettumista $+70^{\circ} \mathrm{C}: \mathrm{ssa}$, muttei $+\mathbf{5 0} 0^{\circ} \mathrm{C}: \mathrm{ssa}$ (LEA ja OLCOTT 1965). Syynä tähän on, että korkeammassa lämpötilassa amiini muodostaa peroksiidien kanssa voimakkaasti antioksidatiivistä dioktyl-N-hydroksylamiinia, joka hidastaa rasvan hapettumista.

Jollakin mausteina käytetyillä kasvinosilla on voitu osoittaa olevan antioksidatiivista tehoa (Chibault ym. 1956, Pratt ym. 1964, Pratt 1965), mutta yleensä tämä lienee vähäinen. Sen sijaan virheellisen maun ja aromin peittäjänä mausteilla tietysti on tärkeä osuus.

Luonnollisten hapetus-inhibiittoreiden lisäksi turvaudutaan kalapuolisäilykkeissä usein lisättyihin antioksidatiivisiin valmisteisiin. Askorbiini- ja erytorbiinihappojen lisäksi on Suomessa tällä hetkellä sallittu butyylihydroksianisolin (BHA) ja butyylihydroksitolueenin (BHT) käyttö. Tehokkaaksi on osoittautunut viimeksimainittujen seos $22.5 \%$ BHA $+9.5 \%$ BHT tweenpohjoisessa valmisteessa (NıKкILÄ ym. 1968). Antioksidantit voidaan lisätä kastikkeeseen välittömästi ennen vähittäismyyntipakkausten täyttämistä. On tärkeää, että kastike kokonaan täyttää tölkin ja että tölkki suljetaan tiiviisti. Kun valmiste säilytetään jääkaappilämpötilassa, valolta suojattuna, ei rasvan hapettumista tapahdu. Purkin avaamisen jälkeen pilaantuu rasva luonnollisesti varsin nopeasti. 


\section{Mikrobiologiset muutokset}

Pyyntihetkellä on kalassa runsaimmin mikrobeja pinnan limassa, kiduksissa ja suolistossa. Pohjoisten vesien kaloilla nämä mikrobit ovat fakultatiivisesti psykrofiilejä maa- ja vesibakteereita. Floorassa ovat enemmistönä gramnegatiiviset sauvat suvuista Pseudomonas, Achromobacter, Flavobacterium sekä kokkeja suvusta Micrococcus (NIKKILÄ 1955 a, Liston 1956, GeorgalA 1957, ERICKSEN 1963). Vähäisemmässä määrin esiintyy lajeja suvuista Proteus, Bacillus, Sarcina ja Corynebacterium. Flooran määrä ja koostumus vaihtelee eri vuodenaikoina. Bakteerien määrä Pohjanmeren sillissä on korkeimmillaan heinä-elokuussa (SHEwAN 1961). Suoliston mikrobien määrään vaikuttaa syöty ravinto. Kutemisajan alussa pyydystettyjen kalojen suolisto sisältää mikrobeja huomattavasti runsaammin kuin myöhemmin syksyllä tai talvella pyydystettyjen, koska kalat tässä vaiheessa ovat lopettaneet ravinnon ottamisen. Pintalimassa ja kiduksissa olevien mikrobien määrä taas vaihtelee ympäristötekijöiden mukaan. Suurimmillaan mikrobisto on keväisin ja syksyisin, jolloin myös planktonia esiintyy runsaimmin (SHEWAN 1961). Myös kalastustavalla on vaikutusta, troolilla pyydystetyssä saaliissa ovat mikrobimäärät suuremmat kuin verkolla pyydetyssä.

\section{1 Mikrobiologiset muutokset pyynnin jälkeen}

Pyydystämisen aikana ja välittömästi sen jälkeen kala saastuu pyyntivälineiden, laivan kannen sekä käsittelytilojen ja -välineiden mikrobeista (SHEwAN 1961, JoNEs 1962). Kalan huuhteleminen ja nopea jäähdytys hidastavat tehokkaasti bakteeriflooran kehittymistä. Toisaalta on tutkimuksissa havaittu (SHEWAN 1961, p. 500), että jäillä suoritettu jäähdytys usein on jopa haitallinen, koska se lisää bakteerikontaminaatiota. Etenkin laivoissa käytettävissä olevat jäät ovat usein voimakkaasti saastuneet huonosti puhdistetuissa varastoissa jo ennen käyttöä. Koneelliset jäähdyttämöt on sen sijaan helpompi puhdistaa käyttökertojen välillä. Sekä osittaisen että täydellisen kalan perkaamisen on todettu edistävän mikrobien leviämistä ja siten nopeuttavan pilaantumista.

Pyynnin jälkeen alkaa kalan kudoksissa välittömästi autolyyttinen proteolyysi (JoNes 1962). Erityisesti ruoansulatuselinten entsyymit, mutta myös lihasten katepsiinit hydrolysoivat proteiineja peptideiksi ja aminohapoiksi. Muodostuneet komponentit edistävät mikrobien lisääntymistä ja kalan pilaantuminen kiihtyy. Koska tynnyrikalaksi valmistettavasta sillistä ei voida poistaa ruoansulatuselimistöä, kuten umpilisäkkeitä ja ohutsuolta estämättä samalla toivottua kypsymistä, on kala suolattava nopeasti, muutaman tunnin kuluessa pyynnin, huuhtelun ja osittaisen perkaamisen jälkeen.

\section{2 Mikrobiologiset muutokset tynnyrikalassa}

Suolaamisen jälkeen mikrobien lukumäärä vähenee nopeasti (ALM 1964). Useimpien bakteerien kasvu estyy, kun suolapitoisuus on yli $10 \%$. Tätä suuremmissa pitoisuuksissa pystyvät lisääntymään vain halofiilit ja fakultatiivisesti halofiilit mikrobit. Tynnyrikalan suolaväkevyys kohoaa usein 15 $\%$ :in, jota sietävät vain harvat, obligatorisesti halofiilit lajit. Tynnyrissä vallitseviin olosuhteisiin sopeutuneen flooran muodostavat lähinnä sukujen 
Micrococcus, Sarcina ja Achromobacter edustajat (NikKILÄ 1955 a, ERICKSEN ym. 1962, ERICKSEN 1973). Mikrobien kokonaismäärä pysyy vähäisenä useiden viikkojen ajan, $(2-9) \times 10^{3} \mathrm{kpl} / \mathrm{ml}$ laukkaa (ERICKSEN 1971), huomattavaa lisääntymistä tapahtuu vasta, kun kala on kypsää (Ascheнough 1952).

Halotolerantit mikrobit ovat usein viime kädessä peräisin käytetyistä tynnyreistä tai suolasta. Paljon harmia ovat aiheuttaneet punaiset, halofiilit bakteerit, joiden pigmentti värjää kalan pinnan. Nykyään, kun käytetyn suolan mikrobipitoisuus on vähäinen, ovat halofiilien aiheuttamat haitat huomattavasti vähentyneet. Obligatorisesti halofiilit mikrobit ovat aerobeja, joten tiiviissä, täyteen pakatussa tynnyrissä ne harvoin kykenevät lisääntymään. Anaerobien mikrobien kasvu estyy yleensä jo $5 \%$ :ssa suolaliukoisessa (NIINIVAARA 1955).

Erittäin haitallinen on mikrobiologinen limanmuodostus, jota yleensä tapahtuu vähittäispakkauksissa, mutta jota voi esiintyä myös tynnyreissä. Lima on dekstraania tai levaania, jota mikrobit muodostavat sakkaroosin glukoosista tai fruktoosista. Limaa muodostavat eräät maitohappobakteerit, joskin kalavalmisteissa lienevät yleisimpiä suvun Achromobacter edustajat (Lindeberg 1956, 1958). Nämä ovat halofiilejä, joille Na-ioni on välttämätön. Optimi-pH on 7. Bakteerit ovat aerobeja, jonka vuoksi tynnyriä avattaessa ei useinkaan voida nähdä sen olevan bakteerien saastuttamaa, vaan liman muodostus alkaa vasta jonkin ajan kuluttua avaamisen jälkeen. Liman muodostajien saastuttamien alueiden, varastojen ja käsittelytilojen puhdistaminen suoritetaan runsaalla makean veden määrällä, joka tehokkaasti tuhoaa näitä halofiilejä mikrobeja.

\section{3 Mikrobiologiset muutokset puolisäilykkeissä}

Valmiiden puolisäilykkeiden mikrobisto koostuu pääasiassa halotolerateista, happoa sietävistä, mikroaerofiileistä lajeista (Aschеноugh 1952, NiккіLё 1955 a, ERICKSEN 1973). Kalassa pyyntihetkellä olleet lukuisat proteolyyttiset lajit ovat tuhoutuneet runsaan suolamäärän vuoksi ja puolisäilykkeiden mikrobit ovatkin pääasiassa fermentatiivisia, usein happoa muodostavia. Niissä voidaan erottaa seuraavat ryhmät (ERICKSEN 1971):

1. - gram-positiiviset, katalaasipositiiviset kokit, jotka kasvavat yksittäin tai ryhminä. Kuuluvat lähinnä heimoon Micrococcaceae. Näitä mikrobeja on sekä tynnyrikalassa että eri ikäisissä puolisäilykkeissä. Joillakin niistä voi olla osuutta valmisteen arominmuodostuksessa,

2. - gram-positiiviset, katalaasinegatiiviset, yksittäin, pareittain tai tetradeina esiintyvät kokit. Mikrobit kuuluvat lähinnä heimoon Lactobacillaceae, sukuun Pediococcus (Jörgensen ja BAK-Henriksen 1958). Ne kehittyvät purkkeihin muutamia viikkoja pakkaamisen jälkeen. Ne eivät muodosta kaasua, mutta alentavat valmisteen $\mathrm{pH}: t a$ ja tekevät näin olosuhteet suotuisiksi seuraavan ryhmän mikrobeille,

3. - gram-positiiviset, katalaasinegatiiviset sauvat useimmiten pitkinä tai lyhyinä ketjuina sekä gram-positiiviset, katalaasinegatiiviset kokit pareittain tai lyhyinä ketjuina. Mikrobit kuuluvat lähinnä sukuihin Lactobacillus ja Leuconostoc. Ne ovat kaasua muodostavia ja yleensä viime vaiheessa pilaavat puolisäilykkeen. 
Kaasua muodostavia mikrobikantoja ei esiinny tuoreessa kalassa, vaan ne tulevat valmisteeseen käsittelyn aikana (Kreutzer 1957, Prutz 1958, Priebe 1962). Näiden heterofermentatiivisten bakteerien vallitsevat kannat voivat vaihdella. Niinpä Ruotsissa vuosina $1960-61$ olivat pullistuneiden purkkien mikrobifloorassa yleisimpiä Leuconostoc mesenteroides-lajit, kun taas vuosina 1964-65 lähinnä Lactobacillus buchneri ja Lactobacillus brevis aiheuttivat kaasunmuodostusta (ERICKSEN 1971). Usein kalastusaluksiin ja myös kalanjalostustehtaisiin ovat pesiytyneet omat kaasuamuodostavien mikrobien kannat, jotka käsittelyn aikana infektoivat valmisteet.

Kylmämarinoiduissa valmisteissa, jotka eivät sisällä sokeria, samat Lactobacillus-tyypit aiheuttavat kaasunmuodostusta kuin sokeria sisältävissä puolisäilykkeissäkin. Marinoitujen valmisteiden runsas happopitoisuus mahdollistaa Lactobacillusten kasvun ilman muiden mikrobien aiheuttamaa $\mathrm{pH}: \mathrm{n}$ laskua. Hiilidioksidi syntyy aminohappojen, lähinnä glutamiinihapon ja arginiinin, dekarboksyloituessa, jolloin $\mathrm{pH}$ samalla kohoaa.

\section{31 Säilöntäaineet}

Sekä tynnyrikalaan että varsinkin puolisäilykkeisiin lisätään mikrobiologisen säilyvyyden varmistamiseksi säilöntäaineita. Suomessa on nykyään sallittu bentsoaatin, p-oksibentsoehapon estereiden, heksametyleenitetramiinin (hexa), sorbaatin ja nitraatin käyttö. Nitraattia ja myös bentsoaattia lisätään usein tynnyrikalaan suolauksen yhteydessä. Osa nitraatista pelkistyy tynnyrikalassa nitriitiksi. Tämän määrä jää tavanomaisesti kuitenkin niin vähäiseksi $0.001 \%$, ettei sillä ole merkitystä bakteerien kasvun hidastajana (NinnivaARa 1955). Sen sijaan nitriitin edelleen pelkistyessä syntyvä hydroksylamiini inhiboi voimakkaasti katalaasia, vetyperoksidia keräytyy kudoksiin ja tämä estää bakteerien kasvua. Nitraattia käytetään paitsi säilyvyyden myös värin parantajana, muodostuva nitrosomyoglobiini antaa kalan lihalle punertavan sävyn.

Säilöntäaineiden vaikutuksesta puolisäilykkeissä on suoritettu useita tutkimuksia (Nikkilä 1955 b, Nikkilä ja Linko 1958, Jörgensen ja BaK-HenrikSen 1958, Ericksen ym. 1962, Ericksen 1963, Shumilova 1968). Nykyään sallituista aineista on ehkä tehokkaimmaksi osoittautunut bentsoaatin ja hexan seos. Hexa hajoaa happamassa liuoksessa ammoniakiksi ja formaldehydiksi. On ilmeistä, että hexan käyttö suurelta osin perustuu viimeksimainitun bakterisidiseen tehoon. Hajoamisreaktiossa

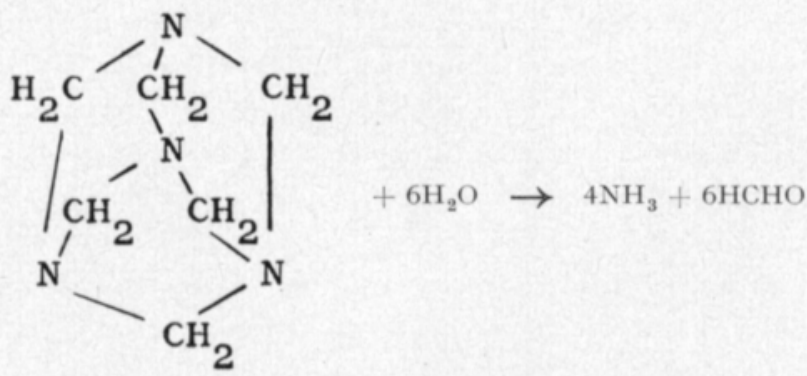

Heksametyleenitetramiini

Formaldehydi 
syntyy tavanomaisessa puolisäilykkeen kastikkeessa tasapaino, kun $\mathbf{5} \%$ hexasta on hajonnut. Kun kalaa on mukana, ei tasapainoa saavuteta, koska formaliini reagoi edelleen proteiinikomponenttien kanssa. Näin ollen reaktio jatkuu, kunnes kaikki hexa on hävinnyt valmisteesta.

Aminohappojen on todettu vähentävän hexan mikrobistaattista vaikutusta (NıккıL̈̈ jа LıNко 1958). Hexa vähentää sillipuolisäilykkeissä tilastollisesti merkitsevästi vapaata lysiiniä ja histidiiniä sekä peptideissä näiden lisäksi vielä glysiiniä (KIESVAARA 1975). Samanlaista eri aminohappoihin kohdistuvaa vaikutusta on myös bentsoaatilla ja sorbaatilla. On näin ollen todennäköistä, että säilöntäaineet tai niiden hajoamistuotteet reagoivat vapaiden aminoryhmien kanssa. Formaliininhan, jota syntyy myös hexan hajotessa, on todettu aiheuttavan proteiinien denaturoitumista (CASTELL ym. 1973 a, 1973 b), mikä voisi tapahtua esim. reaktiossa lysiinin $\varepsilon$-aminoryhmän kanssa.

Bentsoaatin on todettu varsin tehokkaasti estävän kaasua muodostavien bakteerien kasvua (ERICKSEN ym. 1962). Valmisteen suolapitoisuus ja happamuus lisäävät bentsoaatin tehoa (ERICKSEN ym. 1962, NikкILÄ 1955 b). Valmisteissa, joiden $\mathrm{pH}$ on suhteellisen korkea, on edullisempaa käyttää p-oksibentsoehapon estereitä (NikкILÄ ja Linko 1958).

Huonosti veteen liukenevana keräytyy bentsoaatti kalan kudoksiin (Hutschenreuter 1956, Rajama ja KiesvaAra julkaisematon). Jo kolmen vuorokauden kuluttua puolisäilykkeen valmistamisesta ainoastaan $10 \%$ bentsoaatista on vesifaasissa. Teho luonnollisesti kärsii tästä, koska fermentaatioille altis kastike jää vaille bentsoaatin antamaa suojaa.

Mielenkiintoinen puolisäilykkeiden säilöntäaineena on tylosinlaktaatti (ERICKSEN 1967, 1971). Se estää gram-positiivisten bakteerien, erityisesti heterofermentatiivisten Lactobacillusten kasvua ja soveltuu tämän vuoksi erinomaisesti kalapuolisäilykkeisiin. Se kestää korkeitakin suolapitoisuuksia ja on tehokkain happamassa liuoksessa. Kaasun muodostusta estää $10 \mathrm{ppm}$ tylosinlaktaattia yhtä tehokkåasti kuin esim. 500 ppm hexaa tai 1000 ppm bentsoaattia +300 ppm hexaa.

\section{Proteolyyttiset muutokset}

Usein kalapuolisäilykkeiden säilyvyyttä rajoittavaksi tekijäksi muodostuu liian pitkälle edennyt proteolyysi. Kun proteiinien hajoaminen on ehtinyt ns. tyrosiiniasteelle, ts. kun tyrosiini alkaa kiteytyä valmisteesta, katsotaan, ettei valmiste enää vastaa tavanomaiselle kauppatavaralle asetettavia vaatimuksia. Tällöin saostuu kokonaistypestä enää n. $60 \%$ proteiinisaostimilla. Proteolyyttistä pilaantumista tavataan lähinnä maustekalassa ja haarukkapaloissa, harvoin sen sijaan marinoiduissa valmisteisșa. Myös tynnyrikala voi pehmentyä liikaa varastoinnin aikana. Syynä pitkälle jatkuneeseen proteolyysiin on tuoreen kalan korkea peptidaasiaktivisuus sekä aktiivisuuden riittämätön aleneminen suolauksen jälkeen.

Kun kala suolataan välittömästi pyynnin ja esikäsittelyn jälkeen, estyy mikrobien kasvu ja proteolyyttisiä muutoksia aiheuttavat lähinnä lihasten katepsiinit ja ruoansulatuselinten entsyymit. Kalan lihaksessa on varsin aktiivisia katepsiineja (SIEBERT 1961), mutta jo $5 \%$ :n suolaväkevyys inaktivoi ne 
lähes täysin (REDDI ym. 1972). Tynnyrikalan kypsymisen aiheuttavatkin näin ollen ensisijaisesti ruansulatuselinten, lähinnä umpilisäkkeiden, ohutsuolen ja haiman erittämät entsyymit (LujPen 1959, Meyer 1964, Plorina ja Leonova 1971). Myös näiden entsyymien aktiivisuus laskee suolan vaikutuksesta (MARVIK 1973). Kun suolapitoisuus on $5 \%$, on umpilisäkkeiden entsyymien aktiivisuudesta jäljellä $80 \%$. Tynnyrikalan tavanomaisessa suolaväkevyydessä $14-16 \%$ on aktiivisuutta vielä $n$. kymmenesosa alkuperäisestä aktiivisuudesta.

Ruoansulatusentsyymien aktiivisuus vaihtelee kalan ravinnon-oton mukaan. Kun kala ennen kutemisaikaa syö runsaasti, on myös entsyymiaktiivisuus korkea, mutta laskee nopeasti, kun ravinnon ottaminen loppuu (Amano 1961, KAWAI ja IKEDA 1973). Tästä johtuu, että heinä-elokuussa pyydystetty silli kypsyy nopeasti, mutta myöhemmin syksyllä pyydystettyä voidaan säilyttää tynnyrikalana jopa seuraavan kevääseen, kun varastoimislämpötila on riittävän matala.

Kypsymisnopeuteen voidaan jonkin verran vaikuttaa perkaustavalla ja jatkokäsittelyllä. Kalan mahalaukku on perattaessa aina poistettava, koska pepsiini aiheuttaa kypsyvässä kalassa virhemakua (JAN ym. 1972), minkä lisäksi se alentaa toivottujen entsyymien aktiivisuutta. Umpilisäkkeiden ja ohutsuolen osittainen poistaminen alentaa liiallista aktiivisuutta samoin kuin runsas suolamäärä sekä matala säilytyslämpötila.

Puolisäilykkeiden valmistamisen jälkeen tapahtuu niissä aluksi nopea proteolyysi (KIESvAARA 1975), mutta muutaman vuorokauden kuluttua liukoisen typen vapautuminen hidastuu tai pysähtyy kokonaan happamuudesta riippuen. On ilmeistä, että puolisäilykkeissä hapon lisäämisen jälkeen eivät toimi enää samat trypsiinityyppiset entsyymit kuin tynnyrikalassa. Umpilisäkkeiden entsyymien pH-minimi esimerkiksi on 5.0-5.3 (LUIJPEN 1959). Sen sijaan kysymyksessä voivat olla katepsiinityyppiset entsyymit, jotka aiheuttavat proteolyysin myös marinoiduissa valmisteissa (MEYER 1964, KiesvaARA 1975). Happo kuitenkin inaktivoi näitä entsyymeitä, jonka vuoksi sekä marinoidut valmisteet että kypsymättömästä tynnyrikalasta tehdyt haarukkapalat jäävät koviksi ja raa'an makuisiksi. Pehmeästä tynnyrikalasta tehdyissä valmisteissa proteolyysi kuitenkin jatkuu aluksi ilmeisesti eksopeptidaasien, mutta myöhemmin myös endopeptidaasien katalysoimana (KIESvaARA 1975) ja myyntiaika jää lyhyeksi. On mahdollista, että haarukkapalojen proteolyyttisissä muutoksissa on kysymys $\mathrm{pH}: \mathrm{n}$ vaihteluista. Aminohappojen vapautuminen kohottaa $\mathrm{pH}: \mathrm{ta}$, mikä taas aktivoi aluksi kudosten eksopeptidaaseja ja sitten myös endopeptidaaseja ja proteolyysi jatkuu kiihtyvällä nopeudella.

Kalapuolisäilykkeiden laadun kannalta on välttämätöntä, että tynnyrikalan kypsyminen on jatkunut riittävän pitkälle ja että vapaiden aminohappojen määrä valmisteessa ylittää tietyn rajan (3500 $\mu \mathrm{M} / \mathrm{g}$ typpeä) (KIESvAARA 1975). Toisaalta tällaisen valmisteen säilyvyys on rajoitettu. Säilyvyyden parantamiseksi olisikin löydettävä keinoja hidastaa tai kokonaan lopettaa proteolyysi, kun maun kannalta sopiva aste on saavutettu. Tämä koskee yhtähyvin tavanomaisella tavalla kuin myös lisätyillä entsyymeillä kypsytettyjä valmisteita. 
Aktiivisuuden vähentämismahdollisuuksia on tutkittu sekä lämpöä että ionisoivaa säteilyä käyttäen. Umpilisäkkeiden entsyymien aktiivisuus alkaa vähentyä, kun lämpötila kohoaa $+40^{\circ} \mathrm{C}$ :een ja on hävinnyt lähes täysin $+70^{\circ}$ C:ssa (Musch ja Siebert 1971). On ilmeistä, että puolisäilykkeiden käsittelyssä riittäisivät alemmat lämpötilat. Sellaisenaan ei menetelmää kuitenkaan voi käyttää, koska lämpötilan kohottaminen aiheuttaa muutoksia valmisteen maussa.

Ionisoivan säteilyn käyttö on antanut varsin lupaavia tuloksia. Jo $3-\mathbf{8}$ Mrad tuhoaa aktiivisuudesta 50-90\% (Rhodes ja Meegungwan 1962, Musch ja Siebert 1971). Valmisteissa, joissa on runsaasti vapaita aminohappoja, tarvitaan ehkä jonkin verran suurempia säteilymääriä, koska aminohapot vähentävät säteilyn vaikutusta (Musch ja SIEBERT 1971), mutta määrät jäävät joka tapauksessa niin vähỉisiksi, ettei niillä ole vaikutusta makuun. Sovellutuksia ionisoivan säteilytyksen käytöstä kalapuolisäilykkeiden säilyvyyden lisääjinä ei toistaiseksi ole.

\section{Johtopäätökset}

Rasvojen muutoksista sekä mikrobiologisista syistä johtuva puolisäilykkeiden pilaantuminen, ehkä liman muodostusta lukuun ottamatta, on nykyään varsin pitkälle hallittu. Sen sijaan proteolyysin aiheuttamaa säilyvyysajan lyhenemistä ei toistaiseksi ole tyydyttävästi voitu ratkaista. Laadun kannalta ensiluokkaisen suolakalan, tynnyrikalan ja haarukkapalojen myyntiaika rajoittuu 3-4 kuukauteen. Proteolyysiä voidaan hidastaa korkeilla suola- tai happopitoisuuksilla, jotka heikentävät laatua, tai matalilla säilytyslämpötiloilla, jolloin tulokset jäävät suhteellisen vähäisiksi. Tämän vuoksi tutkimukset uusien menetelmien löytämiseksi ovat tarpeen.

\section{KIRJALLISUUTTA}

ALM, F. 1964. The ripening process in Scandinavian anchovy. SIK-rapport 147. Göteborg.

Amano, K. 1961. The influence of fermentation on the nutritive value of fish with special reference to fermented fish products of South-East Asia. Fish in Nutrition, Fishing News Ltd. p. 181. London.

Aschеночgн, V. 1952. The bacteriology of semi sterile fish-preserves especially "gaffelbiter and nanchoviesı. Tidskr. Herm.ind. 38: 30-41.

Castell, C. H., Neal, W. E. \& Dale, J. 1973 a. Comparison of changes in trimethylamine, dimethylamine and extractable protein in iced and frozen gadoid fillets. J. Fish Res. Board Can. 30: 1246-1248.

- - Sмrth, B. \& DYer, W. J. 1973 b. Effect of formaldebyde on salt extractable proteins of gadoid muscle. J. Fish Res. Board Can. 30: 1205-1213.

Chibault, J. H., Mizumo, G. R. \& Lundberg, V. O. 1956. The antioxidant properties of spices in foods. Food Technol. 10: 209-211. 
Erıкскsen, I. 1963. Microflora i fisk och saltade fiskprodukter. SIK-rapport 137. Göteborg. ,--1967 . Effect of tylosin lactate on herring fillets. J. Food Technol. 161-168.

_ - - 1971. Olika konserveringmetoder för sillhalvkonserver. Livsmedelsteknik 1971: 131-134.

,- 1973 . The microflora of semi-preserved fish. Process Biochem. 1973: 21-24.

- - Molin, N. \& TEÄr, J. 1962. On the microflora in semi-preserved fish products. First Int. Congr. Food Sci. Technol. 1962. p. 413-424. London.

FArmer, E. M., Кoch, M. P. \& Sutron, D. A. 1943. The course of autoxidation reaction in polyisoprenes and allied compounds VII. Rearrangement of double bonds during autoxidation. J. Chem. Soc. 1943: 541-543.

- - Sutron, D. A. 1943. The course of autoxidation reactions in the polyisoprenes and allied compounds IV. The isolation and constitution of fotochemically-formed methyloleate peroxide. J. Chem. Soc. 1943: 119-122.

Georgal , D. L. 1957. Changes in the skınflora of god. J. Appl. Bacteriology 20: 23-25.

Hutschenreuter, R. 1956. Beiträge zur Methodik der Konservierungsmittelbestimmung in fischindustriellen Erzeugnissen II. Z. Lebensm. Unters. Forsch. 104: 161-168.

JAN, E., Poнl, F. \& Gödicke, V. 1972. Enzyme mixture for the manufacture of white herring. Offenlegungschrift 2235 996, Bundesrepublik Deutschland Anm. 21 July, 1972. Off. 1 Februar, 1973.

Jannesson, E. \& Marcuse, R. 1956. Amino syror som synergister i salt sill. SIK-publikation 117. Göteborg.

Jones, N. R. 1962. Fish muscle enzymes and their technological significance. Recent advances in food science I. p. 151-166. London.

Jörgensen, B. V. \& BaK-Henriksen, H. A. 1958. The microflora of semipreserved fish products and the use of chemical preservation. Proc. 4th Int. Symp. Food Microbiol. Göteborg 1958.

KawaI, S. \& IKedA, S. 1973. Digestive enzymes of fishes III. Nippon Suisan Gakkaishi 39: 819-823. Ref. CA 79 (1973) 89786n.

KiesvaARA, M. 1975. On the soluble nitrogen fraction in barrel-salted herring and semi-preserves during ripening. Technical Research Centre of Finland. Materials and Processing Technology. Publ. 10.

Kreutzer, R. 1957. Untersuchungen über den biologisch bedingten Verderb von Fischwaren und seine Verhinderung I. Kaltmarinaden Organismen und Milieu. Arch. Fischereiwiss. 8: 104-108.

LeA, C. H. \& Olcotr, M. S. 1965. Antioxidant activity of aliphatic amines. 25th Ann. Meet. Inst. Food Technol. Kansas City Missouri 1965. Ref. Lowry Cocroft Abstracts 11/3/65, $1965,1428$.

- $-\&$ WARD, R. J. 1959. Relative antioxidant activities of the seven tocopherols. J. Sci. Food Agric. 10:537-548.

Lindeberg, G. 1956. Seglake i sillkonserver. SIK-publikation 120. Göteborg.

- - 1958. Levan-producing halophilic bacteria in sugar containing herring brines. SIKpublikation 136. Göteborg.

Linko, R. R. 1967. Fatty acids and other components of Baltic herring flesh lipids. Turun Yliop. Julk. Sarja A 1, 101.

Lisron, J. 1956. Quantitative variations in the bacterial flora of flat fish. J. Gen. Microbiol. 15: 305-307.

LUIJPEN, A. F. M. G. 1959. The influence of gibbing on the ripening of maatjes cured herring. Diss. Univ. Utrecht, $129 \mathrm{p}$.

Marcuse, R. 1960. Antioxidative effect of amino acids. Nature 186: 886-887.

- -1962 . The effect of some amino acids on the oxidation of linoleic acid and its methyl ester. J. Amer. Oil Chem. Soc. 39: 97-103.

Marvik, S. 1973. Proteolytiske reaksjoner i fisk. Föredrag vid seminariet "Enzymatisk bildning och nedbrytning av smak- och aromämnens, Lammi 1973.

MeYer, V. 1964. Úber die Bedeutung proteolytischer Fermente bei der Herstellung nicht sterilisierter Fischwaren. Arch. Fischereiwiss. 15: 245-253.

Musch, K. \& Siebert, G. 1971. Differentzierung von zwei Katepsinen aus Dorschmuskel. Hoppe-Seylers Z. Physiol. Chem. 352: 878-882. 
NinnivaARA, F. P. 1955. Über den Einfluss von Bakterienreinkulturen auf die Reifung und Umrötung der Rohwurst. Acta Agr. Fenn. 84: 1-128.

NıккіL, O. E. 1955 a. Characterization of bacteria responsible for the spoilage of herring preserves. Suom. Kemistilehti B 28:1-3.

- -1955 b. In verdorbenen Heringspreserven vorkommende Bakterie-Arten und ihr Verhalten gegenüber Salz und Konservierungsmitteln. Fette-Seifen-Anstrichmittel - Die Ernährungsindustrie 57: 494-498.

- - - Kiesvaara, M. \& Westergren, K. 1968. Om fettfraktionens oxidation $\mathrm{i}$ fiskhalvkonserver samt hämningen av densamma medelst antioxidanter. Valt. Tekn. Tutk.lait. Tied., Sarja IV - Kemia 97.

- - \& Lisko, R. R. 1958. Chemical preservatives in foodstuffs. The effect on moulds. II. J. Scient. Agric. Soc. Finl. 30: 125-131.

Olley, J. \& Lovern, A. 1960. Phospholipid hydrolysis in cod flesh stored at various temperatures. J. Sci. Food Agric. 11:644-652.

Plorina, A. \& Leonova, A. P. 1971. Role of internal organ enzymes during aging of salted herring. Tr. Balt. Nauch. - Issled. Inst. Rybn. Khoz. 1970, 4:431-441. Ref. CA 75 (1971) $97357 \mathrm{f}$.

Pratr, D. B. 1965. Lipid antioxidants in plant tissue. J. Food Sci. 30: 737-741.

$-\ldots$ Matrs, B. M. 1964. The antioxidant activity of vegetable extracts I. Flavone aglycones. J. Food Sci. 29: 27-33.

Priebe, K. 1962. Zur Frage der Herkunft von Betabakterien (Lactobacterien) bei Heringsmarinaden. Arch. Lebensm. Hyg. 13, 12: 278-280.

Prutz , K. H. 1958. Die Ursache von Bombage in Konserven. Vet. Diss. Berlin.

Rajama, J. \& KiesvaAra, M. Julkaisematon tutkimus.

Reddi, P. K., Constantinides, S. M. \& Dymsza, H. A. 1972. Catheptic activity of fish muscle. J. Food Sci. 37: 643-648.

Rhodes, D. N. \& Meegungwan, C. 1962. Treatment of meats with ionising radiations IX. Inactivation of liver autolytic enzymes. J. Sci. Food Agric. 13: 279-282.

RosenberG, K. 1974. Formaldehydin ja malonaldehydin muodostuminen pakastesilakalla ja niiden vaikutukset proteiinimuutoksiin. Erikoistyöselostus, Helsingin yliopisto. Helsinki.

Shewan, J. M. 1961. The microbiology of sea water fish. Fish as Food I. p. 487-560. Academic Press, New York and London.

Shumilova, M. N. 1968. Effect of sodium benzoate on the quality of spicily pickled anchovies and sardelles. Ryb Khoz. 44:60-62. Ref. CA 70 (1969) 30513d.

Siebert, G. 1961. Enzymes of marine fish muscle and their role in fish spoilage. Fish in Nutrition, Fishing News Ltd. p. 80-82. London. 